\title{
Riparian Evapotranspiration in Nebraska
}

Although riparian vegetation covers a limited amount of land surface within Nebraska (fig. 1), a common belief is that these narrow, linear tracts of vegetation use water at or near the maximum possible rate (potential evapotranspiration rate) because of the availability of surface water and shallow groundwater for transpiration and photosynthesis. Evapotranspiration (ET) is a transfer of water to the atmosphere by means of the combined action of evaporation and plant transpiration through photosynthesis. With increasing demands being placed on the water resources of Nebraska, ET

from riparian communities has become a concern to water users and managers. Although riparian vegetation water use has been researched for many years in more arid regions, such as the desert Southwest, only in the past 10 years has a broader effort been made that included measuring riparian ET in Nebraska (fig.1). Because riparian plant communities generally are found in areas with shallow groundwater, some believe that these communities consume water at or near their maximum potential rates.

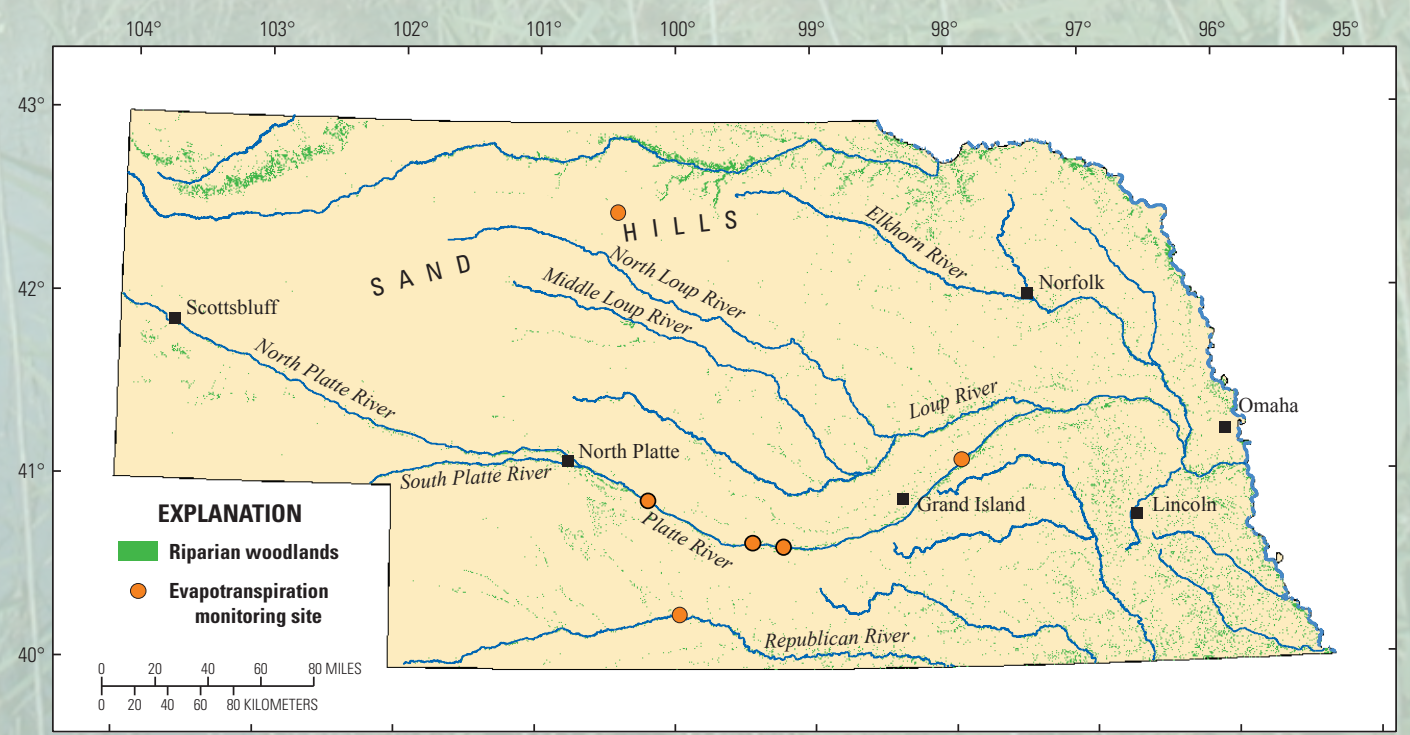

Potential ET rates are likely to vary considerably across any area as large and climatically diverse as Nebraska. Sharma and Irmak (2012) estimated annual potential evaporation ranging from 40 inches in the eastern part of the State to more than 68 inches in the southern panhandle.

Nebraska's riparian communities are dominated by eastern cottonwood (Populus deltoides) with a varying understory of shrubs, trees, and grasses (Huddle and others, 2011). Historically, Nebraska's riparian areas were widely forested, but have undergone changes such as the clearing of woodlands for settlement. Riparian woodlands have become re-established, first by pioneer species such as cottonwoods and willows, and more recently by other native and invasive vegetation in the understory (Huddle and others, 2011). In addition to the woody vegetation, Nebraska's riparian corridors also have seen a change in species composition, most notably the widespread invasion by the common reed, Phragmites australis, which readily grows in the channels of shallow waterways.

Previous studies (Burba and others, 1999; Landon and others, 2009) have attempted to quantify ET rates of different riparian vegetation communities in Nebraska. Several of these investigated the ET of Phragmites, woodlands, and grasslands, which will be summarized herein. Unless otherwise stated, all ET rates and totals given herein are for the growing season (generally May-October).

Figure 1. Riparian woodlands and evapotranspiration (ET) study sites within Nebraska. 


\section{Phragmites}

ET rates of Phragmites-dominated communities have been measured using varying techniques in Nebraska (fig. 2). Burba and others (1999) used the Bowen ratio/ energy-balance system to monitor ET from a Sand Hills wetland with emergent Phragmites vegetation. During the peak growing season, ET rates averaged 0.15 inches per day for the monitoring period of June through October 1994.

In another Phragmites-dominated wetland, further south in the Republican River Basin, Lenters and others (2011) used an infrared heat-flux sensor coupled with an energy balance and a water balance to measure ET throughout the 2009 growing season (April-October). With daily ET rates averaging 0.17 inches per day, this Phragmites community used 30.5 inches throughout the course of the growing season, 64 percent more than the reported precipitation of 18.5 inches for the same time period.

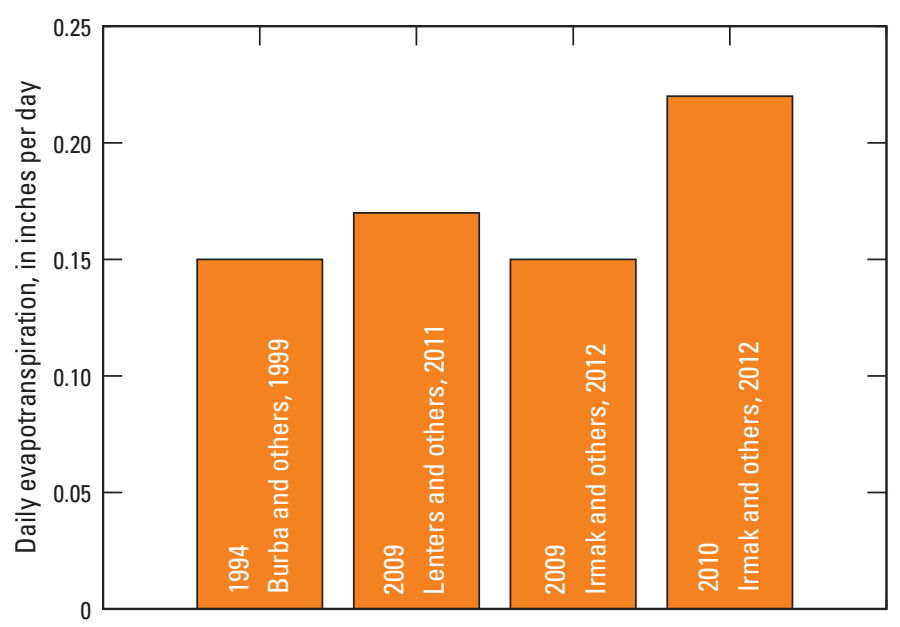

Figure 2. Measured average daily growing-season evapotranspiration rates in Phragmites-dominated riparian plant communities in Nebraska.

Phragmites also are established along the Platte River, and ET was studied at a Phragmites-dominated island in the central Platte River throughout two growing seasons (2009 and 2010) using a Bowen ratio/energy-balance system approach (Irmak and others, 2013; Kabenge, 2011). In the first year of study, the season-long (MayOctober) average daily ET rate was 0.15 inches per day. During the second year, high river levels provided standing water for much of the growing season. This resulted in greater ET, with an average daily rate of 0.22 inches per day. During the May-through-October monitoring season, ET totaled 26.7 inches in 2009 and 38.7 inches in 2010.

These three studies detailing four growing seasons of Phragmites communities in central and southern Nebraska report an average daily ET rate of 0.17 inches per day during the growing season.

\section{Cottonwood Woodlands}

A study of ET rates for two different cottonwooddominated riparian woodlands along the central Platte River performed by Landon and others (2009) used the eddy-covariance approach during drought years from 2002 to 2005 . Both sites were on islands between braided channels, and the woodlands differed primarily in the understory vegetation, with one site dominated by roughleaf dogwood shrubs (Cornus drummondii) and the other site dominated by eastern redcedar trees (Juniperus virginiana). During the 4 years of the study, the site with the eastern redcedar understory had a growing-season (May-October) average ET rate of 0.10 inches per day, totaling an average of 18.3 inches during the 6-month growing season. The growing-season average ET rate for the riparian woodland with a dogwood shrub understory also was 0.10 inches per day, with an average 6-month total ET of 17.6 inches. Since ET was monitored yearround for the entire 4 years it was possible to compare the annual totals of precipitation and evapotranspiration. Annual ET at the site with the eastern redcedar understory ranged from 21.1 to 24.3 inches, with a 4-year average of 22.6 inches, whereas the annual ET at the site with the dogwood shrub understory ranged from 20.2 to 23.1 inches, with a 4-year average of 21.7 inches. The measurements indicated that ET exceeded precipitation in only 1 year at each site, leading to a net groundwater recharge for the study period for both sites. The ET monitoring using eddy-covariance methods at the riparian woodland site with the dogwood shrub understory was continued during comparatively wet years from 2008 to 2009 and 2011 (Hall and Rus, 2013). Higher ET rates were measured during the wetter period (fig. 3) with a growing-season average of 0.13 inches per day and average seasonal total of 24.8 inches. The increased ET also exceeded precipitation by greater than 2.6 inches for 2 of the 3 years of study.

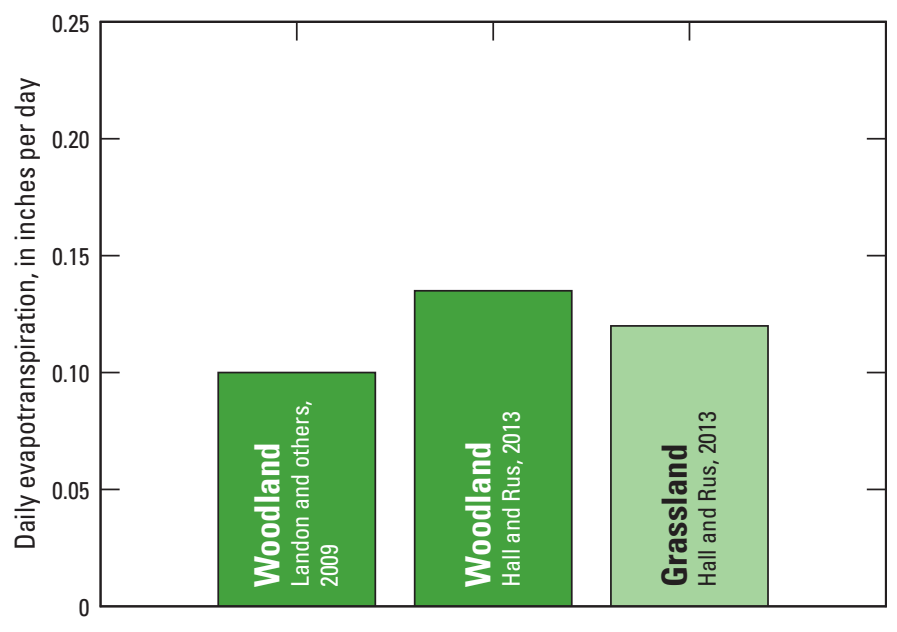

Figure 3. Measured average daily growing-season evapotranspiration rates in riparian woodland and grassland communities in Nebraska, 2002-05, 2008-09, and 2011. 


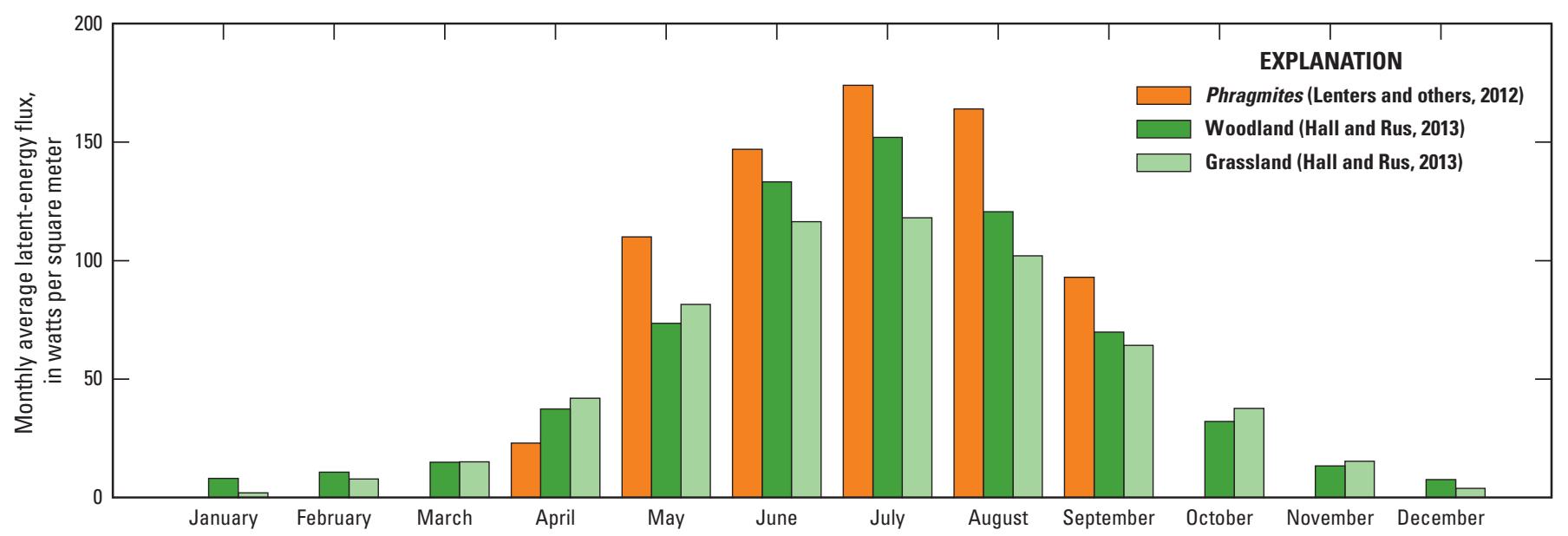

Figure 4. Monthly latent-energy flux in Phragmites in Nebraska, 2009. Average monthly latent-energy flux in riparian woodland and grassland in Nebraska, 2008-09, and 2011.

\section{Grasslands}

The study by Hall and Rus (2013) also measured ET for the same 3 years from a riparian grassland pasture. Grazing occurred in 2008 and 2009 but not in 2011. Using eddy-covariance techniques, average daily growing-season ET was 0.12 inches per day with an average seasonal total of 22.1 inches. This ET was less than that for the riparian woodland; however, the grassland was dominated by cool-season grasses, giving the grassland a longer growing season than the woodland, and ET rates slightly higher than those measured in the woodlands during the spring and fall months. For 2 of the 3 years of the study, the net difference between grassland ET and precipitation was less than 1 inch, but during 2008 precipitation greatly exceeded ET.

\section{Vegetation Comparison}

Latent-energy flux is related directly to ET and represents the movement of energy associated with water vapor. Latent-energy flux is the parameter typically measured in ET studies and is converted to ET mass flux by dividing by water density and latent heat of vaporization of water. A comparison of monthly latent-energy flux shows the timing and magnitude differences between the plant communities (fig. 4). The woodland site data and Phragmites site data show a pronounced mid-summer peak of latent-energy flux, whereas the cool-season activity of the grassland is evident by the higher ET during the spring and fall relative to the woodland.

The co-occurrence of multiple studies during the growing season of 2009 allowed for a direct comparison of ET rates for three vegetation communities (table 1). The Phragmites study sites in the Republican and Platte River Basins had higher average daily ET ( 0.17 and 0.15 inches per day, respectively) than either the riparian woodland or the riparian grassland. The woodland site showed only slightly lower average ET ( 0.13 inches per day) than the Phragmites site. Although grazing likely affected the ET rates, the grassland ET was lower than either of the other vegetation communities with an average daily ET of 0.10 inches per day.

The woodland site studied by Landon and others (2009) and Hall and Rus (2013) showed a change in ET relations during the study periods. Perhaps most striking in this comparison was the increased annual ET during 2008-11 despite precipitation totals and potential ET rates that were within the same range as those monitored from 2002 to 2005 (fig. 5). Hall and Rus (2013) report two primary reasons for the increase in ET. Groundwater levels were higher during 2008-11 than they were during 2002-05, reducing the effects of water limitation on the plants. As a result, the vegetation vigor likely was improved during 2008-11 compared to the droughtaffected years from 2002-05.

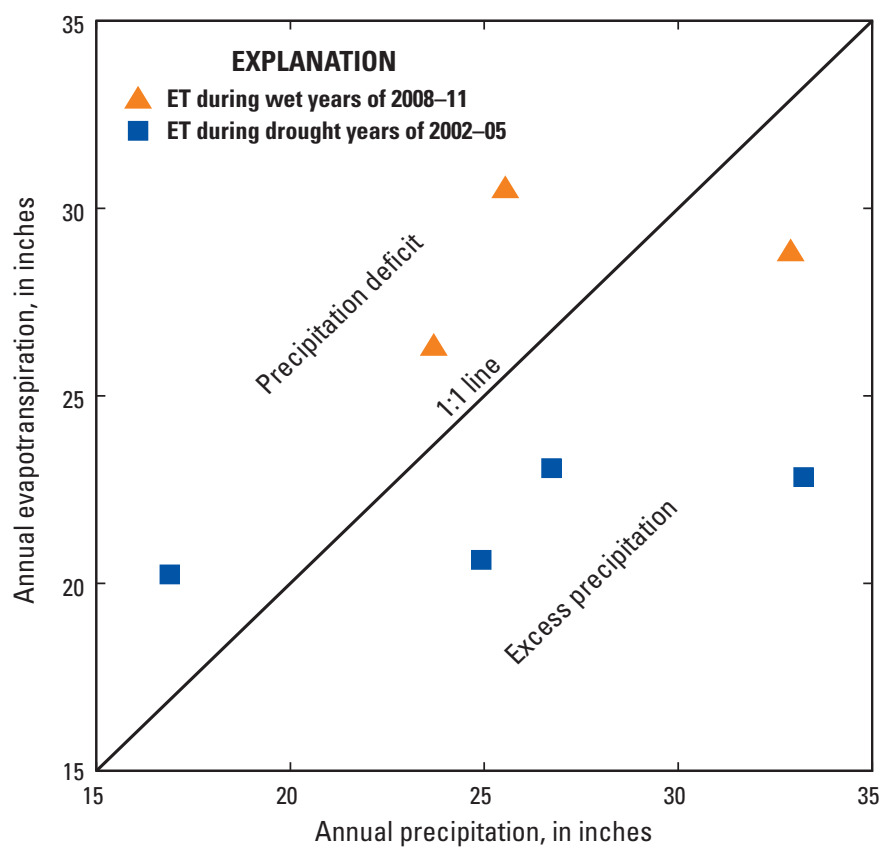

Figure 5. Differences in the relation of evapotranspiration (ET) and precipitation of a riparian woodland in Nebraska, 2002-05, 2008-09, and 2011. 
Table 1. Average and maximum daily growing-season evapotranspiration in riparian plant communities in Nebraska.

$[--$, not applicable $]$

Growing season (May-October) daily evapotranspiration, in inches per day

\begin{tabular}{|c|c|c|c|c|c|c|}
\hline \multirow[t]{2}{*}{ Plant community } & \multirow[t]{2}{*}{ Evapotranspiration study } & \multicolumn{2}{|c|}{2009} & \multicolumn{3}{|c|}{ All referenced studies, various years } \\
\hline & & Average & Maximum & Number of seasons & Average & Average maximum \\
\hline Woodland & Hall and Rus, 2013 & 0.13 & 0.34 & 11 & 0.11 & 0.28 \\
\hline Grassland & Hall and Rus, 2013 & 0.10 & 0.23 & 3 & 0.12 & 0.25 \\
\hline Phragmites & Lenters and others, 2011 & 0.17 & 0.32 & 4 & 0.17 & 0.33 \\
\hline
\end{tabular}

\section{References Cited}

Burba, G.G., Verma, S.B., and Kim, J., 1999, Surface energy fluxes of Phragmites australis in a prairie wetland: Agricultural and Forest Meteorology, v. 94, p. 31-51.

Hall, B.M., and Rus, D.L., 2013, Comparison of water consumption in two riparian vegetation communities along the central Platte River, Nebraska, 2008-09 and 2011: U.S. Geological Survey Scientific Investigations Report 2013-5203, 28 p.

Huddle, J.A, Awada, T., Martin, D.L., Zhou, X., Pegg, S.E., and Josiah, S.J., 2011, Do invasive riparian woody plants affect hydrology and ecosystem processes?: Great Plains Research, v. 21, p. 49-71.

Irmak, S., Kabenge, I., Rudnick, D., Knezevic, S., Woodward, D., and Moravek, M., 2013, Evapotranspiration crop coefficients for mixed riparian plant community and transpiration crop coefficients for common reed, cottonwood, and peach-leaf willow in the Platte River basin, Nebraska-USA: Journal of Hydrology, v. 481, p. $177-190$.
Kabenge, I., 2011, Sotmatal and canopy resistance, plant physiological parameters, evapotranspiration and other surface energy fluxes of Phragmites-dominated riparian plant community in the Platte River Basin, Nebraska, USA: Lincoln, University of Nebraska-Lincoln, Ph.D. dissertation, $376 \mathrm{p}$.

Landon, M.K., Rus, D.L., Dietsch, B.J., Johnson, M.R., and Eggemeyer, K.D., 2009, Evapotranspiration rates from riparian forests, Platte River, Nebraska, 2002-06: U.S. Geological Survey Scientific Investigations Report 2008-5228, 65 p.

Lenters, J.D., Cutrell, G.J., Istanbulluoglu, E., Scott, D.T., Herrman, K.S., Irmak, A., and Eisenhauer, D.E., 2011, Seasonal energy and water balance of a Phragmites australis-dominated wetland in the Republican River basin of south-central Nebraska (USA): Journal of Hydrology, v. 408, p. 19-34.

Sharma, V., and Irmak, S., 2012, Mapping spatially interpolated precipitation, reference evapotranspiration, actual crop evaporation, and net irrigation requirements in Nebraska-Part I. Precipitation and reference evapotranspiration: Transactions of the ASABE, v. 55, no. 3, p. 907-921.

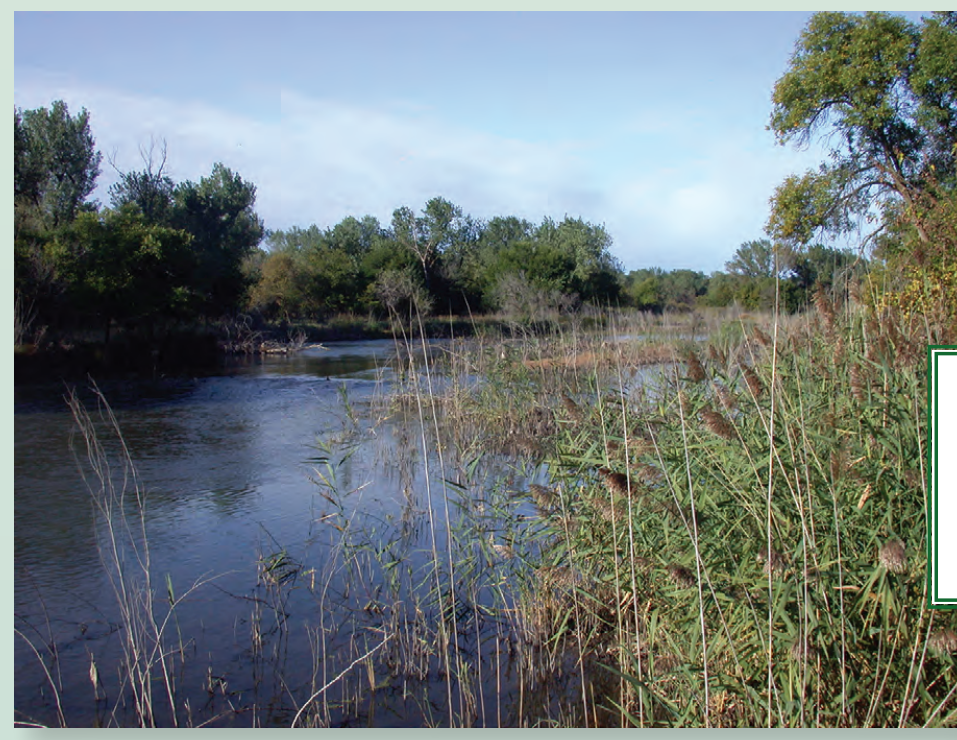

Photograph of riparian vegetation along the north channel of the Platte River near Odessa, Nebraska, taken September 21, 2011, by Brent Hall.

\section{For additional information contact:}

Director, USGS Nebraska Water Science Center 5231 South 19th Street

Lincoln, Nebraska 68512

(402) 328-4100 